\title{
Reintroduction and stock enhancement of European weatherfish (Misgurnus fossilis L.) in Rhineland-Palatinate and Hesse, Germany
}

\author{
Benjamin Schreiber ${ }^{1, *}$, Egbert Korte ${ }^{2}$, Thomas Schmidt ${ }^{1,3}$ and Ralf Schulz ${ }^{1,3}$ \\ ${ }^{1}$ Institute for Environmental Sciences, University of Koblenz-Landau, Fortstrasse 7, 76829 Landau, Germany \\ ${ }^{2}$ Institut für Gewässer- und Auenökologie GbR, Riedstadt, Germany \\ ${ }^{3}$ Eusserthal Ecosystem Research Station, University of Koblenz-Landau, Birkenthalstrasse 13, 76857 Eusserthal, Germany
}

\begin{abstract}
A stocking program for the endangered European weatherfish (Misgurnus fossilis L.) was conducted in the German federal states of Rhineland-Palatinate and Hesse, southwest Germany. An initial monitoring enabled to identify local broodstock and to assess habitats regarding their ecological suitability for reintroduction. In a second step, broodstock were caught for artificial propagation and cultured fry were released in previously selected river sectors. Furthermore, reintroduction sectors were biannually monitored to assess stocking success. Within the study period (2014-2016), a total number of approximately 83,500 juveniles were stocked in three river sectors for reintroduction and approximately 85,000 juveniles were stocked in four other river sectors to strengthen existing populations. During the post-release monitoring, 45 individuals were recaptured in two sectors. The documented short-term reintroduction success (i.e. survival of released individuals) indicates appropriateness of the selected stocking strategy. Furthermore, the provided course of action might be transferred to further states or countries and thereby contribute to weatherfish conservation at larger scales.
\end{abstract}

Keywords: conservation / artificial propagation / endangered species / stocking / Rhine

Résumé - Réintroduction et soutien de la loche d'étang (Misgurnus fossilis L.) en Rhénanie-Palatinat et en Hesse, Allemagne. Un programme d'empoissonnement pour la loche d'étang menacée (Misgurnus fossilis L.) a été mené dans les états fédéraux allemands de Rhénanie-Palatinat et de Hesse, au sud-ouest de l'Allemagne. Un premier suivi a permis d'identifier les stocks de géniteurs locaux et d'évaluer les habitats en fonction de leur aptitude écologique à la réintroduction. Dans un deuxième temps, les géniteurs ont été capturés pour la reproduction artificielle et les alevins d'élevage ont été relâchés dans des secteurs fluviaux préalablement sélectionnés. De plus, les secteurs de réintroduction ont fait l'objet d'un suivi semestriel pour évaluer le succès de l'empoissonnement. Au cours de la période étudiée (2014-2016), un nombre total d'environ 83,500 juvéniles ont été déversés dans trois secteurs fluviaux pour réintroduction et environ 85,000 juvéniles ont été déversés dans quatre autres secteurs fluviaux pour renforcer les populations existantes. Au cours de la surveillance après déversement, 45 individus ont été recapturés dans deux secteurs. Le succès documenté de la réintroduction à court terme (c.-à-d. la survie des individus relâchés) indique que la stratégie d'empoissonnement choisie est appropriée. De plus, les mesures prévues pourraient être transférées à d'autres états ou pays et contribuer ainsi à la conservation de la loche d'étang à plus grande échelle.

Mots-clés : conservation / propagation artificielle / espèces menacées / empoissonnement / Rhin

\section{Introduction}

The world's fish fauna is increasingly threatened by impacts of the expansion of human populations, including (i) competition for water, (ii) habitat alteration, (iii) pollution,

\footnotetext{
*Corresponding author: benjaschreiber@gmail.com
}

(iv) introduction of exotic species and (v) commercial exploitation (Moyle and Leidy, 1992; Clausen and York, 2008). On the European red list of freshwater fishes (2011), $37 \%$ of 531 occurring native species are listed as threatened at a continental scale and $17 \%$ show declining populations (Freyhof and Brooks, 2011). In contrast to fish species of high public attention like European sturgeon (Acipenser sturio) or Atlantic salmon (Salmo salar) that are used as conservation 
flagships for European major rivers (Ludwig, 2006; Monnerjahn, 2011), other endangered species with low economic value might be overlooked and neglected by conservation efforts (Kalinkat et al., 2016). This latter category includes the European weatherfish (Misgurnus fossilis L.).

The European weatherfish belongs to the Cobitidae family and occurs in densely vegetated river areas with muddy substratum, including oxbows, flood plains or ditch systems (Lelek, 1987; Kottelat and Freyhof, 2007). It is a demersal species native to Europe that can be found north of the Alps, from the Volga basin to France (Lelek, 1987). Presumably, as a result of habitat degradation, management practices in secondary habitats and water pollution, weatherfish populations declined or even became extinct in many regions across its original range (Koščo et al., 2008; Drozd et al., 2009; Hartvich et al., 2010). However, only few of the mentioned reasons have so far been investigated with specific relation to the conservation of weatherfish. Investigations by Meyer and Hinrichs (2000) indicated that weatherfish populations found in ditch systems are mainly endangered by intensive mechanical maintenance like dredging or weeding measures. Studies that were conducted in order to evaluate potential threats posed by chemical stress indicated that weatherfish embryos are highly sensitive to contaminants dissolved in water and contaminants associated with sediments (Schreiber et al., 2017a, 2018). Today, the weatherfish is listed under Annex II of the Habitats Directive 92/43/EEC and classified as vulnerable or nearly extinct on Red Lists of numerous countries, including Austria, Czech Republic, Denmark, Germany, Hungary, Slovakia, Slovenia and Switzerland (EU, 1992; Zulka and Wallner, 2006; Haupt et al., 2009; Hartvich et al., 2010; Sigsgaard et al., 2015).

Restoration of habitats and removal of invasive species are key strategies to support the viability of existing freshwater fish populations (Cochran-Biedermann et al., 2015). However, the increasing number of eradications of fish species from parts of their historical range led to enhanced use of reintroduction measures for conservation purposes (Armstrong and Seddon, 2008; Tatár et al., 2017). In the case of weatherfish, (Lelek, 1987) also recommended the reintroduction of hatchery-reared individuals to areas with suitable conditions. In general, there is agreement that every conservational reintroduction practice should be well documented and that standardization along guidelines can increase the reintroduction outcome (IUCN, 1987, 1998, 2013; Lee and Hughes, 2008; Sutherland et al., 2010).

In order to counteract the ongoing decline of weatherfish populations, a regional joint conservation program in RhinelandPalatinate and Hesse (southwest Germany) was initiated in 2014. The program area lies at the southwestern boundary of the species distribution range and is supposed to play a significant role for weatherfish conservation on a national level as the Rhine floodplains provide rare primary habitats for this species (Copp, 1989; Dister et al., 1990). Main objectives of the program were determined as (i) to support existing weatherfish populations by stock enhancement and (ii) to reintroduce this species in sectors with suitable conditions where the specific reasons for its eradication can be excluded. For both objectives, hatcheryreared weatherfish fry derived from local broodstock should be utilized (Lelek, 1987). The aim of the present paper was to comprehensively document all necessary steps of the mentioned program, from the planning stage to the implementation, as well as to critically discuss achieved objectives and remaining challenges and to identify opportunities for improvement.

\section{Methods}

\subsection{Initial monitoring: identification of broodstock and reintroduction habitats}

As a first step, an initial monitoring within the study area was carried out to identify (i) relic weatherfish populations for broodstock sampling and (ii) potential areas for reintroduction measures that meet the species requirements. Selection of the specific monitoring regions was made on the basis of available data of past weatherfish detections (unpublished) and on the identification of potential areas on topographic maps. In total, 144 river sectors, belonging to 10 catchments, were monitored for weatherfish presence via fish traps (total number of trap nights $=1948)$ or electro-fishing (total electro-fishing distance $=$ $2700 \mathrm{~m}$ ) between 2007 and 2016 (Tab. S1 in the supporting information). The used drum-shaped fish traps were equipped with baits. During the monitoring, traps were distributed for one night in the investigated sectors with distances of 5-10 m between each trap (depending on the width of the respective sector). In order to allow trap-caught weatherfish to swallow air from above the water surface, traps were placed in the water without full immersion. Electro-fishing was only carried out in water sectors with lower vegetation densities by using batterypowered devices (EFGI 650 and EFGI 4000; Bretschneider Spezialelektronik, Chemnitz, Germany).

Concerning the habitat assessments for an identification of reintroduction sites, special attention was given to good connectivity and year-round water bearing and none to moderate maintenance practices (e.g. mowing of the banks), presence of spawning habitats (i.e. connected flood plains) and absence of nocturnal predators (in particular, the European eel - Anguilla anguilla L.). Occasional presence of low numbers of other piscivorous predators (e.g. Esox lucius) was not defined as a criterion for excluding the site for a reintroduction.

\subsection{Captive breeding and rearing of fish}

For the broodstock sampling, weatherfish spawners were caught with baited fish traps at the beginning of the spawning season (March to April) as already described. Subsequently, individuals from different populations origin were maintained separately. Artificial propagation followed the procedure reported by Schreiber et al. (2017b). In brief, males and females were isolated from each other, and water temperature was gradually increased to $18^{\circ} \mathrm{C}$, before a gonadotropinreleasing hormone $(\mathrm{GnRH})$ containing preparation (Ovopel, Unic-trade) was intramuscularly injected in two divided doses. Stripped eggs of one female were fertilized with sperm of two males and subsequently transferred to hatching troughs. Incubation of embryos $\left(18^{\circ} \mathrm{C}\right)$ and rearing of larvae $\left(21^{\circ} \mathrm{C}\right)$ was carried out in recirculation aquaculture systems. Weatherfish fry were fed with Artemia salina nauplii and reared until they reached a total length $\left(L_{\mathrm{T}}\right)$ of approximately $2-4 \mathrm{~cm}$. This rearing duration was chosen as it represents a feasible 
compromise to overcome the most sensitive life stage and to limit the adaptation to artificial conditions.

\subsection{Stocking procedure and post-release monitoring}

One half of the cultured fry was released in areas where the broodstock was originated (i.e. endogenous enhancement). The other half was used for reintroductions in habitats that were previously assessed as suitable (Tab. 2). The only exception to this procedure happened at waters of the Schwarzbach catchment $\left(49^{\circ} 59^{\prime} 6.4^{\prime \prime} \mathrm{N} ; 8^{\circ} 29^{\prime} 42.1^{\prime \prime}\right.$ E): here, endogenous enhancement was not possible so that fry from the Horloff catchment were used for stock enhancement (i.e. exogenous enhancement).

Stocking was carried out in several batches per year and site by evenly distributing weatherfish fry in shallow and densely vegetated water stretches. Prior to release, fish were gently acclimated to the on-site water conditions (e.g. temperature) by placing the fish containing buckets in the water and gradually adding water from the releasing site to the buckets. Batches of cultured fish were divided and stocked in several sectors to limit the risk linked to unpredictable fluctuations in water level (Meyer and Hinrichs, 2000), which might negatively influence their survival.

Stocking success was monitored biannually in late summer from the first year of stocking (2014) by using fish traps. As stocked individuals could not be distinguished from previously occurring weatherfish, only sectors selected for reintroduction could be used for a reliable assessment of the efficiency of the stocking.

\subsection{Documentation and assessment of the program}

In order to provide a standardized documentation and assessment of the conducted program, a questionnaire template that was originally designed for waterbird re-establishment programs (Lee and Hughes, 2008) was completed in a slightly adapted form (Tab. S2 in the supporting information).

Furthermore, the costs per released individual were estimated, including the following work stages: (i) broodstock sampling, (ii) captive breeding, (iii) rearing of fish and (iv) stocking procedure. For the estimation, acquisition costs were neglected (e.g. fish traps, electro-fishing device, establishment of an aquacultural system) and staff expenses were included for two different educational levels (i.e. research associate and research assistant). Ongoing costs that arise during the rearing of fish (e.g. electricity, feed, wear of the aquacultural system) were taken into account by calculating a fixed amount per day. In total, 151 working hours of a research associate (40 Euro per h), 257 working hours of a research assistant ( 15 Euro per $h$ ) and 48 days of ongoing costs ( 25 Euro per day) were included, resulting in an aggregate amount of 11,095 Euro per stocking season.

\section{Results}

\subsection{Initial monitoring: identification of broodstock and reintroduction habitats}

In the initial monitoring, weatherfish populations suitable for broodstock sampling were detected in four catchments
(Horloff: $50^{\circ} 25^{\prime} 14.7^{\prime \prime} \mathrm{N}, 8^{\circ} 52^{\prime} 44.9^{\prime \prime} \mathrm{E}$; Queich: $49^{\circ} 13^{\prime} 19.4^{\prime \prime} \mathrm{N}$, $8^{\circ} 15^{\prime} 13.1^{\prime \prime} \mathrm{E}$; Streitgraben: $49^{\circ} 05^{\prime} 43.0^{\prime \prime} \mathrm{N}, 8^{\circ} 19^{\prime} 03.7^{\prime \prime} \mathrm{E}$; Weschnitz: $\left.49^{\circ} 40^{\prime} 25.5^{\prime \prime} \mathrm{N}, 8^{\circ} 34^{\prime} 56.1^{\prime \prime} \mathrm{E}\right)$. Furthermore, three catchments were assessed as suitable for weatherfish reintroduction (Gersprenz: $49^{\circ} 50^{\prime} 54.8^{\prime \prime} \mathrm{N}, 8^{\circ} 50^{\prime} 46.0^{\prime \prime} \mathrm{E}$; Rhein: $49^{\circ} 38^{\prime} 45.9^{\prime \prime} \mathrm{N}, 8^{\circ} 24^{\prime} 30.7^{\prime \prime}$ E; Speyerbach: $49^{\circ} 18^{\prime} 49.0^{\prime \prime} \mathrm{N}$; $8^{\circ} 17^{\prime} 23.1^{\prime \prime} \mathrm{E}$ ) (Tab. 1). A table with all sites investigated during the initial monitoring can be found in the supporting information (Tab. S1).

\subsection{Stocking of weatherfish}

During the study period (2014-2016), approximately 275,000 eggs were produced from 38 females (mean $L_{\mathrm{T}} \pm$ standard deviation $(\mathrm{SD})=202 \pm 27 \mathrm{~mm}$; mean wet mass $\left.\left(M_{\mathrm{W}}\right) \pm \mathrm{SD}=47 \pm 15 \mathrm{~g}\right)$. From these eggs, approximately 168,500 individuals reached the juvenile stage (resulting mortality rate: $39 \%$ ) and were released in identified sectors (Fig. 1; Tab. 2). On the basis of a mean number of 56,167 released individuals per stocking season, the conducted cost estimation revealed an expenditure of approximately 0.20 Euro per released individual.

\subsection{Post-release monitoring}

In the Gersprenz catchment, seven individuals (size class: $7-8 \mathrm{~cm}$ ) were recaptured in 2015 (40 traps) and one individual $(10 \mathrm{~cm})$ in 2016 (50 traps). In the Rhein catchment, 37 individuals of two size classes (34 individuals of 10-14 cm and 3 individuals of $16-18 \mathrm{~cm}$ ) were recaptured in 2016 (40 traps) (Tab. 3).

\section{Discussion}

The low number of weatherfish populations identified during the initial monitoring (Tab. 1; Tab. S1) illustrates the species' critical situation within the study area (i.e. southwest Germany) and consequently underlines the need for conservation measures. However, the successful determination of weatherfish refuges ensured the opportunity of broodstock sampling from populations that might be genetically adapted to local conditions - a factor considered crucial for reintroduction success (Weeks et al., 2011; Cochran-Biederman et al., 2015). A genetic characterization of the populations selected for broodstock sampling might further improve the reintroduction strategy with respect to prioritization possibilities (Attard et al., 2016; Schmidt et al., 2017). Numerous ditch systems located in the study area generally met the species requirements but lacked suitable spawning habitats like floodplains because ditches typically prevent water from bursting its banks (Dollinger et al., 2015). This observation might explain the frequently reported absence of juvenile weatherfish in comparable systems and leads to the assumption that successful reproduction in ditches might be limited to years with high water levels in spring. As the long-term absence of appropriate spawning habitats can result in a lack of reproduction success, stock enhancement might be particularly effective in these systems. Generally, highly artificial water systems that are inhabited by 
Table 1. Catchments investigated in the initial monitoring that were either selected as suitable for broodstock sampling (Horloff, Queich, Streitgraben, Weschnitz) or for weatherfish reintroduction (Gersprenz, Rhein, Speyerbach). Furthermore, information includes the number of investigated sectors per catchment, the number of fish traps, the electro-fishing distance and the number of caught weatherfish.

\begin{tabular}{lllll}
\hline Catchment & No. of investigated sectors & No. of fish traps & Electrofishing distance (m) & No. of caught weatherfish \\
\hline Gersprenz $^{*}$ & 6 & 262 & - & 0 \\
Horloff $^{* *}$ & 17 & 170 & 500 & 49 \\
Queich $^{* *}$ & 15 & 150 & - & 7 \\
Rhein $^{*}$ & 6 & 131 & 300 & 0 \\
Schwarzbach $^{* * *}$ & 3 & 373 & 200 & 1 \\
Speyerbach $^{*}$ & 7 & 120 & 100 & 0 \\
Streitgraben $^{* *}$ & 2 & 60 & - & 44 \\
Weschnitz $^{* *}$ & 13 & 482 & - & 124 \\
Total & 69 & 1748 & 1100 & 225 \\
\hline
\end{tabular}

${ }^{*}$ Catchments selected for reintroduction of weatherfish.

** Catchments selected for broodstock sampling and endogenous enhancement.

*** Catchment selected for exogenous enhancement.
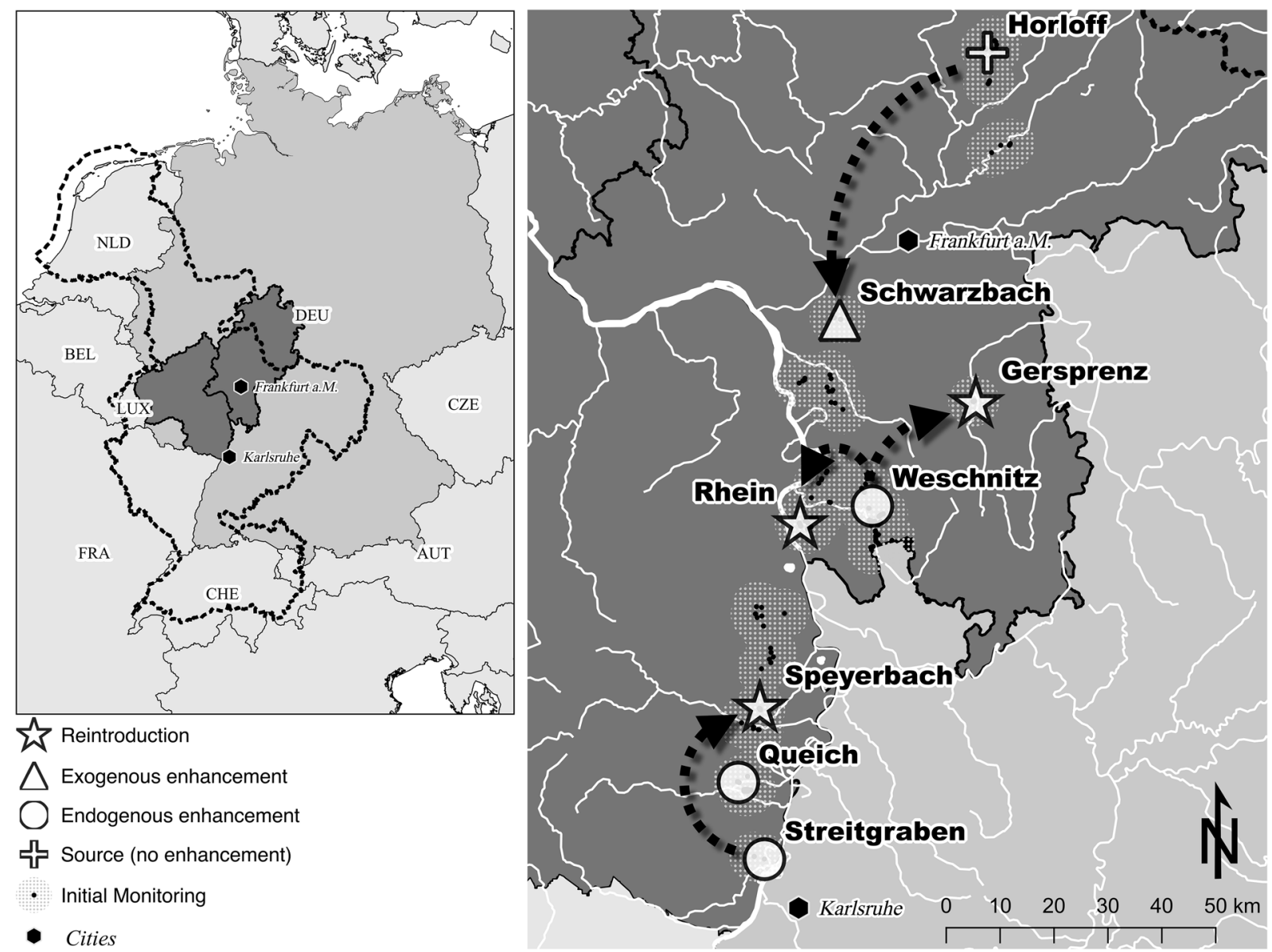

Fig. 1. Map of the study area. Overview map on the left shows the location of the federal states of Rhineland-Palatinate and Hesse (dark grey) in Germany (grey) and Europe (light grey; GADM, 2012), including codes of the countries bordering Germany. The dotted black line indicates the international Rhine river basin district (European Environment Agency, 2011). Detailed map on the right shows the sectors investigated in the initial monitoring, catchments used for the different stocking measures (reintroduction, endogenous enhancement, exogenous enhancement) and the broodstock source used where no enhancement took place (Horloff). Black arrows indicate the broodstock origin used for reintroductions. White lines show main rivers (GADM, 2012). 
Table 2. Number of weatherfish released into the selected water sections, subdivided by stock enhancement and reintroduction measures. Information includes year of stocking, stocked catchment and the broodstock origin. For a geographical orientation, the reader is referred to Figure 1.

\begin{tabular}{|c|c|c|c|c|c|}
\hline \multirow[b]{2}{*}{ Year of stocking } & \multicolumn{2}{|c|}{ Stock enhancement } & \multicolumn{3}{|c|}{ Reintroduction } \\
\hline & $\begin{array}{l}\text { Stocked } \\
\text { catchment }\end{array}$ & $\begin{array}{l}\text { No. of released } \\
\text { individuals }\end{array}$ & Stocked catchment & $\begin{array}{l}\text { No. of released } \\
\text { individuals }\end{array}$ & $\begin{array}{l}\text { Broodstock origin } \\
\text { (catchment) }\end{array}$ \\
\hline 2014 & Streitgraben $^{*}$ & 24,000 & Speyerbach & 11,000 & Streitgraben \\
\hline 2014 & Weschnitz $^{*}$ & 12,000 & Gersprenz & 13,000 & Weschnitz \\
\hline Total for 2014 & - & 36,000 & - & 24,000 & - \\
\hline 2015 & Streitgraben $^{*}$ & 13,000 & Speyerbach & 7,500 & Streitgraben \\
\hline 2015 & Queich $^{*}$ & 10,000 & Gersprenz & 8,000 & Weschnitz \\
\hline 2015 & - & - & Rhein & 18,000 & Weschnitz \\
\hline Total for 2015 & - & 23,000 & - & 33,500 & - \\
\hline 2016 & Streitgraben ${ }^{*}$ & 6,000 & Speyerbach & 14,000 & Streitgraben \\
\hline 2016 & Schwarzbach $^{* *}$ & 20,000 & Gersprenz & 5,000 & Horloff \\
\hline 2016 & - & - & Rhein & 7,000 & Horloff \\
\hline Total for 2016 & - & 26,000 & - & 26,000 & - \\
\hline Total & - & 85,000 & - & 83,500 & - \\
\hline
\end{tabular}

${ }_{* *}^{*}$ Stocking site is equivalent to the site of broodstock origin (i.e. endogenous enhancement).

** Broodstock originates from the Horloff catchment (i.e. exogenous enhancement).

Table 3. Number of recaptured individuals from weatherfish post-release monitoring conducted in areas used for reintroduction, including year and date of monitoring, name of the monitored catchment, number of fish traps, number of recaptured individuals and size class of recaptured individuals.

\begin{tabular}{llllll}
\hline Year & Dates & Catchment & No. of fish traps & No. of recaptured individuals & Size class (cm) \\
\hline 2015 & 23 September and 30 October & Gersprenz & 40 & 7 & $7-8$ \\
2016 & 22 September & Rhein & 40 & 34 & $10-14$ \\
& & & 3 & $16-18$ \\
2016 & 27 September and 18 October & Gersprenz & 50 & 1 & 10 \\
Total & - & - & 130 & 45 & - \\
\hline
\end{tabular}

weatherfish as secondary habitats (e.g. ditch systems) are difficult to manage from a conservation point of view, as they are built by humans to drain water from the field. Thus, management activities that might be conducted to allow for the development of flood plains might counteract the original usage of these waters. However, since the weatherfish is listed under Annex II of the Habitats Directive 92/43/EEC, sites with weatherfish occurrence must be managed in accordance with the ecological needs of the species.

The methods used for assisted reproduction and rearing of juvenile weatherfish can be considered as efficient to address the objectives considered in the present program as sufficient stocking material could be provided every year $(\geq 52,000$ juveniles per year) (Tab. 2). A good feasibility of weatherfish production was previously reported in several studies (Kouril et al., 1996; Demény et al., 2009). However, comprehensive investigations on the thermal requirements of weatherfish larvae carried out along with the program helped to increase their survival and growth rates during the rearing period (Schreiber et al., 2017b). This illustrates how scientific guidance of different steps in comparable conservation programs may improve the prospects and hence is explicitly recommended.
The total number (45) of individuals recaptured at two reintroduction sites can be considered as relatively high because traditional capturing methods (e.g. fish traps or electro-fishing) were frequently reported as inefficient when applied for weatherfish (Meyer and Hinrichs, 2000; Sigsgaard et al., 2015) (Tab. 3). A solution to these problems might be the implementation of environmental DNA (eDNA) monitoring (Sigsgaard et al., 2015). Increasing catching efforts and eDNA sampling are planned for the near future, especially for the third so far unsuccessfully monitored reintroduction site (Speyerbach). However, the clear size classification of recaptured individuals indicates a certain survival of stocked weatherfish (Tab. 3). Therefore, it can be assumed that the conducted habitat assessment indicated suitable waters for reintroduction and that the stocking strategy is generally appropriate (for reintroduction and stock enhancement). Since weatherfish reach maturity after 2-3 years (Kottelat and Freyhof, 2007), a confirmation of successful reproduction and estimations about the establishment of self-sustainable reintroduced populations (IUCN, 1998) is still pending. However, as the presence of appropriate spawning habitats was considered as crucial, natural reproduction in the stocked sectors is considered a realistic prospect. In order to assess the 
success of stock enhancement, the establishment of a chemical marking protocol for weatherfish fry is possible (e.g. with oxytetracycline). However, marking success and mortality during marking are hard to predict as the outcome of both is driven by various factors (Hundt et al., 2015). Furthermore, a parental assignment based on microsatellite markers can be a promising alternative, but the polyploidy of weatherfish might limit the feasibility of this method (Drozd et al., 2010; Zhao et al., 2015). The possibility of using passive integrated transponders (PIT-tags) for tagging of juvenile weatherfish prior to release was discussed within this project as well. However, since the small size of the stocked individuals $\left(L_{\mathrm{T}}=2-4 \mathrm{~cm}\right)$ prevented a save injection of the smallest available transponders $(12 \mathrm{~mm})$, PIT-tagging of the stock material would have required an extended rearing duration prior to release, which might negatively influence the survival of individuals after release. Furthermore, as the detection efficiency of PIT-tags negatively correlates with the density of marked fish in the reading area of the antenna, the release of tagged individuals in great quantities might limit the explanatory power of this method (Schmidt et al., 2016). In order to investigate the fate of released individuals, as well as to gain more insights into the movement activity of weatherfish in general, an additional study with larger PIT-tagged individuals is intended within the project at a later stage.

A factor that needs more attention within the continuing implementation of the project is an increased involvement of socio-economic aspects, since the acceptance and support of local people can positively influence the outcome of reintroduction programs (IUCN, 1987, 1998, 2013; Bajomi et al., 2013). This particular potential for improvement of the project could be identified by completing the questionnaire template drafted by Lee and Hughes (2008) (Tab. S2). Furthermore, the questionnaire provides the possibility to document reintroduction programs in a standardized way (Sutherland et al., 2010). However, as it was originally designed for waterbird re-establishment programs, the questionnaire had to be slightly adopted for an application for fish reintroduction. The revealed expenditure of 0.20 Euro per released individual constitutes an estimation based on assumptions only applicable for the circumstances under which the present program was conducted (e.g. existing infrastructure). Moreover, as the program is part of a larger scientific project with additional investigations of other aspects than stocking activities (Schreiber et al., 2017a, 2017b, 2018), only approximations could be provided. Therefore, it has to be emphasized that additional costs that were excluded from the presented calculation (e.g. acquisition costs, investments needed for other work stages) might lead to expenditures that are much higher or lower than estimated.

As a conclusion, indicators for short-term success of reintroduction and stock enhancement measures conducted with hatchery-reared weatherfish fry could be detected (i.e. survival of released individuals) but indicators for long-term success (i.e. spawning of reintroduced individuals) are still pending. Consequently, the present approach might be effective for further federal states and countries with critical populations, but for sustainable improvements, stocking has to be maintained in future and individual steps can be refined.

\section{Supplementary Material}

Supplementary figures and tables.

The Supplementary Material is available at https://www. kmae-journal.org $/ 10.1051 / \mathrm{kmae} / 2018031 / \mathrm{olm}$.

Acknowledgements. The authors would like to thank for financial support by Struktur- und Genehmigungsdirektion Süd (RheinlandPfalz), Regierungspräsidium Darmstadt (Hessen), and Hessisches Landesamt für Naturschutz, Umwelt und Geologie. Furthermore, as parts of the study were conducted at the Eusserthal Ecosystem Research Station, University of Koblenz-Landau, we would like to thank the research station staff.

\section{References}

Armstrong DP, Seddon PJ. 2008. Directions in reintroduction biology. Trends Ecol Evol 23: 20-25.

Attard CRM, Möller LM, Sasaki M, Hammer MP, Bice CM, Brauer CJ, Carvalho DC, Harris JO, Beheregaray LB. 2016. A novel holistic framework for genetic-based captive-breeding and reintroduction programs. Conserv Biol 30: 1060-1069.

Bajomi B, Tatár S, Tóth B, Demény F, Trenovszki MM, Urbányi B, Müller T. 2013. Captive-breeding, re-introduction and supplementation of European mudminnow in Hungary. In: Soorae, PS, ed. Global Re-introduction Perspectives: 2013. Further Case Studies from Around the Globe. Gland, Switzerland; Abu-Dhabi, United Arab Emirates: IUCN/SSC Re-introduction Specialist Group, Environmental Agency, pp. 15-20.

Clausen R, York R. 2008. Global biodiversity decline of marine and freshwater fish: a cross-national analysis of economic, demographic, and ecological influences. Soc Sci Res 37: 1310-1320.

Cochran-Biederman JL, Wyman KE, French WE, Loppnow GL. 2015. Identifying correlates of success and failure of native freshwater fish reintroductions. Conserv Biol 29: 175-186.

Copp GH. 1989. The habitat diversity and fish reproductive function of floodplain ecosystems. Environ Biol Fishes 26: 1-27.

Demény F, Zöldi LG, Deli Zs, Fazekas G, Urbányi B, Müller T. 2009. Artificial propagation and rearing of weatherfish (Misgurnus fossilis) in the interest of natural stock maintenance. Pisces Hungarici 3: 107-113.

Dister E, Gomer D, Obrdlik P, Petermann P, Schneider E. 1990. Water management and ecological perspectives of the upper Rhine's floodplains. River Res Appl 5: 1-15.

Dollinger J, Dagès C, Bailly JS, Lagacherie P, Voltz M. 2015. Managing ditches for agroecological engineering of landscape: a review. Agron Sustain Dev 35: 999-1020.

Drozd B, Kouril J, Blaha M, Hamackova J. 2009. Effect of temperature on early life history in weatherfish, Misgurnus fossilis (L 1758). Knowl Manag Aquat Ecosyst 392: 1-17.

Drozd B, Flajšhans M, Ráb P. 2010. Sympatric occurrence of triploid, aneuploid and tetraploid weatherfish Misgurnus fossilis (Cypriniformes, Cobitidae). J Fish Biol 77: 2163-2170.

EU 1992. Council Directive 92/43/EEC on the conservation of natural habitats and wild fauna and flora. Official J Eur Union L206: 1-66.

European Environment Agency 2011. WISE River basin districts (RBDs) - version 1.4. Retrieved from https://www.eea.europa.eu/ data-and-maps/data/wise-river-basin-districts-rbds- 1 .

Freyhof J, Brooks E. 2011. European red list of freshwater fishes. Publications Office of the European Union, Luxembourg, 61 p.

GADM 2012. GADM database of Global Administrative Areas Version 2.0. Retrieved from http://gadm.org/. 
Hartvich P, Lusk S, Rutkayová J. 2010. Threatened fishes of the world: Misgurnus fossilis (Linnaeus, 1758) (Cobitidae). Environ Biol Fishes 87: 39-40.

Haupt H, Ludwig G, Gruttke H, Binot-Hafke M, Otto C, Pauly A. 2009. Rote Liste gefährdeter Tiere, Pflanzen und Pilze Deutschlands, Band: Wirbeltiere. Bundesamt für Naturschutz, Münster, Germany.

Hundt M, Schreiber B, Eckmann R, Lunestad BT, Wünneman H, Schulz R. 2015. The effect of water hardness on mortality of zebrafish (Danio rerio) during exposure to oxytetracycline. Bull Environ Contam Toxicol 96: 144-149.

IUCN 1987. The IUCN Position Statement on Translocation of Living Organisms: Introductions, Reintroductions and Re-Stocking, $13 \mathrm{p}$.

IUCN 1998. Guidelines for Re-introductions. Cambridge: IUCN/SSC Re-introduction Specialist Group, $10 \mathrm{p}$.

IUCN 2013. Guidelines for Reintroductions and Other Conservation Translocations, Version 1.0. IUCN Species Survival Commission, p. 57.

Kalinkat G, Cabral JS, Darwall W, Ficetola GF, Fisher JL, Giling DP, Gosselin M-P, Grossart H-P, Jähnig SC, Jeschke JM, Knopf K, Larsen S, Onandia G, Paetzig M, Saul W-C, Singer G, Sperfeld E, Jarić I. 2016. Flagship umbrella species needed for the conservation of overlooked aquatic biodiversity. Conserv Biol 31: $1-12$.

Koščo J, Lusk S, Pekárik L, Košuthová L, Lusková V, Košuth P. 2008. The occurrence and status of species of the genera Cobitis, Sabanejewia, and Misgurnus in Slovakia. Folia Zool 57: 26-34.

Kottelat M, Freyhof J. 2007. Handbook of European Freshwater Fishes, Cornol, Switzerland and Berlin, Germany: Kottelat, $646 \mathrm{p}$.

Kouril J, Hamácková J, Adámek Z, Sukop I, Stibranyiová I, Vachta R. 1996. The artificial propagation and culture of young weatherfish (Misgurnus fossilis L.). Conserv Endanger Freshw Fish Eur: 305-310.

Lee R, Hughes B. 2008. Review of Waterbird Re-establishment in the AEWA Area. Document No. AEWA/MOP 4.11. Retrieved from http://www.unep-aewa.org/sites/default/files/document/lwfg_re cap2 5 re wb re-establishment.pdf.

Lelek A. 1987. The Freshwater Fishes of Europe - Threatened Fishes of Europe. Wiesbaden, Germany: AULA Verlag, 343 p.

Ludwig A, 2006. A sturgeon view on conservation genetics. Eur $J$ Wildlife Res 52: 3-8.

Meyer L, Hinrichs D. 2000. Microhabitat preferences and movements of the weatherfish, Misgurnus fossilis, in a drainage channel. Environ Biol Fishes 58: 297-306.
Monnerjahn U. 2011. Atlantic Salmon (Salmo salar L.) reintroduction in Germany: a status report on national programmes and activities. $J$ Appl Ichthyol 27: 33-40.

Moyle PB, Leidy RA. 1992. Loss of biodiversity in aquatic ecosystems: evidence from fish faunas. Conserv Biol: 127-169.

Schmidt T, Löb C, Schreiber B, Schulz R. 2016. A pitfall with PIT tags: reduced detection efficiency of half-duplex passive integrated transponders in groups of marked fish. $N$ Am J Fish Manag 36: 951-957.

Schmidt T, Zagars M, Roze A, Schulz R. 2017. Genetic diversity of a Daugava basin brown trout (Salmo trutta) brood stock. Knowl Manag Aquat Ecosyst 418: 55.

Schreiber B, Petrenz M, Monka J, Drozd B, Hollert H, Schulz R. 2017a. Weatherfish (Misgurnus fossilis) as a new species for toxicity testing? Aquat Toxicol 183: 46-53.

Schreiber B, Monka J, Drozd B, Hundt M, Weiss M, Oswald T, Gergs R, Schulz R. 2017b. Thermal requirements for growth, survival and aerobic performance of weather fish larvae Misgurnus fossilis. $J$ Fish Biol 90: 1597-1608.

Schreiber B, Fischer J, Schiwy S, Hollert H, Schulz R. 2018. Towards more ecological relevance in sediment toxicity testing with fish: evaluation of multiple bioassays with embryos of the benthic weather fish (Misgurnus fossilis). Sci Total Environ 619-620: 391-400.

Sigsgaard EE, Carl H, Møller PR, Thomsen PF. 2015. Monitoring the near-extinct European weather loach in Denmark based on environmental DNA from water samples. Biol Conserv 183: 46-52.

Sutherland WJ, Armstrong D, Butchart SHM, Earnhardt JM, Ewen J, Jamieson I, Jones CG, Lee R, Newbery P, Nichols JD, Parker KA, Sarrazin F, Seddon PJ, Shah N, Tatayah V. 2010. Standards for documenting and monitoring bird reintroduction projects. Conserv Lett 3: 229-235.

Tatár S, Bajomi B, Specziár A, Tóth B, Müllerné Trenovszki M, Urbányi B, Csányi B, Szekeres J, Müller T. 2017. Habitat establishment, captive breeding and conservation translocation to save threatened populations of the vulnerable European mudminnow Umbra krameri. Oryx 51: 718-729.

Weeks AR, Sgro CM, Young AG, Frankham R, Mitchell NJ, Miller KA, Byrne M, Coates DJ, Eldridge MDB, Sunnucks P, Breed MF, James EA, Hoffmann AA. 2011. Assessing the benefits and risks of translocations in changing environments: a genetic perspective. Evol Appl 4: 709-725.

Zhao N, Qiao Y, Zhu B, Liao XL, Pan L, Chang JB. 2015. Identification ability of tetraploid microsatellite loci in parentage analysis. J Appl Ichthyol 31: 614-619.

Zulka KP, Wallner RM. 2006. Rote Listen gefährdeter Tiere Österreichs. Kriechtiere, Lurche, Fische, Nachtfalter, Weichtiere (Grüne Reihe des Landesministeriums). Böhlau Verlag, Vienna.

Cite this article as: Schreiber B, Korte E, Schmidt T, Schulz R. 2018. Reintroduction and stock enhancement of European weatherfish (Misgurnus fossilis L.) in Rhineland-Palatinate and Hesse, Germany. Knowl. Manag. Aquat. Ecosyst., 419, 43. 